\title{
Health and education concerns about returning to campus and online learning during the COVID-19 pandemic among US undergraduate STEM majors
}

\author{
Lindsay E. Palmer, $\mathrm{MS}^{1,2,3}$, Sherry L. Pagoto, $\mathrm{PhD}^{4}$, Deja Workman ${ }^{1}$, \\ Kathrine A. Lewis, MS ${ }^{1,2,3}$, Lauren R. Rudin ${ }^{4}$, Nina De Luna ${ }^{1}$, Valeria Herrera, BS RDN", \\ Nathanial Brown, $\mathrm{PhD}^{1}$, Jessica Bibeau, $\mathrm{MA}^{4}$, Kaylei Arcangel, $\mathrm{MS}^{4}$, Molly E. Waring, $\mathrm{PhD}^{4 *}$ \\ ${ }^{1}$ Department of Mathematics, The Pennsylvania State University, University Park, PA \\ ${ }^{2}$ Department of Psychology, The Pennsylvania State University, University Park, PA \\ ${ }^{3}$ Department of Women's, Gender, and Sexuality Studies, The Pennsylvania State University, \\ University Park, PA \\ ${ }^{4}$ Department of Allied Health Sciences, University of Connecticut, Storrs, CT \\ * Corresponding author: \\ Molly E. Waring, PhD \\ Department of Allied Health Sciences \\ University of Connecticut \\ 358 Mansfield Road, Unit 1101 \\ Storrs, CT 06269-1101 \\ Phone (860) 486-1446 \\ Emailmolly.waring@uconn.edu \\ Twitter @DrMollyWaring \\ ORCID: 0000-0002-9884-9824
}




\begin{abstract}
Objective: We examined undergraduate students’ concerns about returning to campus and about online learning from home.

Participants: Undergraduates majoring in STEM at US universities/colleges.

Methods: Participants completed an online survey in July 2020. We content-analyzed responses to open-ended questions about concerns about Fall 2020.

Results: Students (N=64) were 52\% women, 47\% low SES, and 73\% races/ethnicities other than non-Hispanic white. Concerns about returning to campus included student noncompliance with university COVID-19 prevention guidelines (28\%), infection risk (26\%), poor instructional quality (26\%), inadequate university plans for preventing/handling outbreaks (25\%), negative impacts on social interactions (11\%), and transportation/commuting (11\%). Concerns about online learning from home included difficulty focusing on schoolwork (58\%), lack of handson/experiential learning (24\%), negative impacts on social interactions (19\%), family/home environment (15\%), concerns that online learning wastes time/money (10\%), and inadequate technology/Internet access (5\%).

Conclusions: Universities should address student concerns and provide resources to overcome barriers to effective learning.
\end{abstract}

Keywords: COVID-19; undergraduate students; education; online learning 


\section{Introduction}

In response to the COVID-19 pandemic, colleges and universities forced many students to relocate and transition to remote instruction in mid-March 2020. This abrupt shift to online learning disrupted undergraduate education, raising student concerns about academic performance, ability to graduate ${ }^{1}$, and career opportunities ${ }^{2}$. Across the US, many universities' reopening plans for Fall 2020 include a campus return for a minority of students while providing online learning for remaining students. Universities opening their campuses developed safety policies ${ }^{3}$ to prevent COVID-19 infections ${ }^{4}$, yet some schools have seen COVID-19 incidence proliferate, resulting in a shift to online learning for all ${ }^{5}$.

For undergraduate students majoring in STEM (Science, Technology, Engineering, and Mathematics), a shift to virtual learning may be particularly disruptive as many courses involve hands-on components difficult to recreate virtually (e.g., laboratory). Further, the pandemic has impacted the job market for STEM majors in terms of marketable skills and employment opportunities. An increasingly competitive and evolving job market ${ }^{6,7}$ presents more than just academic and financial concerns for students but also access to health insurance and other benefits (e.g., retirement) because these depend on employment. Finally, many STEM fields do not represent the diversity of the US ${ }^{8}$, making these majors an important target for programming that offsets the educational impact of the pandemic.

Understanding STEM students’ concerns about on campus and online learning during the pandemic is imperative to planning efforts for this and future disruptions to STEM education ${ }^{9}$. The impact on college students is likely to intensify as the pandemic continues ${ }^{10}$, putting an entire cohort of students at risk for poor educational outcomes. A return to normal will require COVID-19 vaccination rates high enough to attain herd immunity which may not be possible 
until late 2021 at the soonest ${ }^{11}$ and this timeline is threatened by high rates of COVID-19 vaccine hesitancy ${ }^{12}$. Experts predict future pandemics and natural disasters due to factors such as deforestation and climate change so future campus disruptions can be expected ${ }^{13,14}$. Universities need guidance on how to shape their plans to respond to public emergencies to maximize the educational success of students while minimizing attrition, especially among STEM majors from historically-excluded groups.

In this qualitative study, we examined concerns of a diverse sample of STEM undergraduate students about both returning to campus and online learning from home during the Fall 2020 semester. The goals of this study are to identify problems associated with on-campus and remote online learning during the pandemic and to identify areas for future research that will enhance our ability to meet the educational needs of STEM students.

\section{Methods}

In July 2020, we recruited undergraduate students attending US colleges/universities to participate in a study about their experiences transitioning to online learning due to COVID-19 in Spring 2020. Participants completed a 30-minute survey ${ }^{15}$ and participated in a focus group stratified by gender (women, men), socioeconomic status (SES; low, higher), and race/ethnicity (non-Hispanic white/Middle Eastern, Hispanic/Latinx, non-Hispanic Black, non-Hispanic Asian). Participants received a \$50 gift card. The Penn State and University of Connecticut Institutional Review Boards approved this study.

We recruited students by posting on STEM-related subreddits and by emailing course listservs. Faculty in the Math Alliance, a national organization of faculty in mathematics, forwarded a recruitment email to their students and other faculty teaching calculus courses required by many STEM majors. Interested individuals completed a brief initial eligibility 
screener ${ }^{15}$. Eligible students were aged 18 years or older, enrolled full-time in a college/university in the United States in Spring 2020, declared or intended STEM major, and met criteria for inclusion in one of 16 focus groups stratified by gender, SES, and race/ethnicity. STEM majors included students who had a declared major within the natural sciences (e.g., biology, physics), engineering, mathematics, and technology (e.g., computer science), but excluded students in the social sciences (e.g., psychology). Participants reported their gender as woman, man, or with an 'other' write-in option; students who did not identify as women or men were excluded. Participants reported whether they identified their ethnicity as Hispanic/Latinx, and reported how they describe their race(s), including Native American (e.g., American Indian, Alaskan Native, Indigenous), Native Hawaiian/Pacific Islander, Black/African American, White/Caucasian, Middle Eastern/Arab American, South East/East Asian (e.g., Malaysian, Vietnamese, Chinese, Japanese), or South Asian (e.g., Indian, Sri Lankan). Based on responses, we categorized participants as non-Hispanic white/Middle Eastern, Hispanic/Latinx (any race[s]), non-Hispanic Black, non-Hispanic Asian, or other race/ethnicity; participants identifying as another race/ethnicity or as non-Hispanic multiracial were excluded from participation. Students were categorized as low SES if they met 1+ of the following criteria: (1) were eligible for work study or Pell grants, (2) reported that it was very hard for their family to pay for basics (e.g., rent, heat, food), or (3) parental education of at most a high school diploma or GED combined with a household income $<\$ 75,000$. Students were categorized as higher SES if they met all of the following criteria: (1) were not eligible for work study, (2) were not eligible for a Pell Grant, (3) reported that it was not hard at all or somewhat hard to pay for basics, and (4) parental education was a Bachelor's degree or higher. Students whose responses did not place them in either of the above groups were excluded from participation. Of the 416 respondents to 
the initial eligibility screener, we invited the 154 eligible individuals to participate in genderSES-race/ethnicity focus groups (max 6 students per group). The current study reports on students' concerns about Fall 2020 reported by the 64 students who completed the survey.

The survey included questions assessing demographics, their situation in Spring 2020 (e.g., academic performance, courses, employment) and concerns about the Fall 2020 semester. Participants were asked two questions about how concerned and excited they were about returning to campus in the fall (5-point scale from not at all concern/excited to extremely concerned/excited). Participants were then asked two open-ended questions about what concerns they had about returning to campus and concerns about staying home and learning online in Fall 2020.

\section{Statistical analysis}

We summarized participant characteristics and Likert items about excitement and concern using descriptive statistics. We conducted a directed content analysis ${ }^{16}$ of the responses to the open-ended questions related to concerns about Fall 2020. For the question on concerns about returning to campus, one student did not provide a response and 6 students said they would be staying home; we analyzed responses from 57 students. For the question about concerns about online learning at home, three students left this question blank, one said they were returning to campus, and one wrote “n/a”; we analyzed responses from 59 students. We developed a codebook after an initial review of participant responses. Two coders (LR, VH) reviewed all responses and coded the presence of each theme (69-98\% agreement across themes). A third researcher (MEW) reviewed discrepantly-coded responses and adjudicated. Quantitative analyses were conducted using SAS 9.4 (SAS Institute, Inc, Cary, NC).

\section{Results}


Students ( $\mathrm{n}=64)$ were $52 \%$ women, $47 \%$ low SES, and $73 \%$ identified as races/ethnicities other than non-Hispanic white (Table 1). In Spring 2020, participants were enrolled in 32 US colleges/universities, including private colleges/universities ( $n=4,13 \%$ of schools), public universities ( $\mathrm{n}=27,78 \%)$, and community colleges $(\mathrm{n}=3,9 \%)$. When surveyed in July 2020, students were living in 20 US states/territories including Puerto Rico, with two students living outside the US. Six percent $(\mathrm{n}=4)$ of students were not all concerned about returning to campus, $25 \%(n=16)$ were slightly concerned, $23 \%(n=15)$ were somewhat concerned, $28 \%(n=18)$ were moderately concerned, and $17 \%(n=11)$ were extremely concerned. More than a quarter $(27 \%$, $n=17)$ were not at all excited about returning to campus, $13 \%(n=8)$ were slightly excited, $22 \%$ $(n=14)$ were somewhat excited, $16 \%(n=10)$ were moderately excited, and 22\% ( $n=14)$ were extremely excited.

When asked about concerns about returning to campus in Fall 2020, 63\% (n=36) of students shared one concern, 30\% $(n=17)$ shared two concerns, $5 \%(n=3)$ shared three concerns, and $2 \%(n=1)$ shared four concerns. The most common concern, shared by $28 \%(n=16)$ of students, was other students' noncompliance to university/college guidelines to prevent COVID19 infection on campus, including social distancing and mask wearing (Table 2). Some students expressed specific concerns about roommates' behavior while others expressed concerns about students on-campus generally. The second most common concern, voiced by $26 \%(n=15)$ of students, was becoming infected with COVID-19, including concerns about subsequently infecting family members. Twenty-six percent $(n=15)$ of students reported concerns about instructional quality and access to resources (e.g., tutoring, library). A quarter of students (25\%; $\mathrm{n}=14$ ) were concerned about their university's plan for preventing COVID-19 infection, including the university's potential response to an outbreak and financial repercussions of 
another sudden campus closing (e.g., not being refunded for housing costs). Eleven percent ( $\mathrm{n}=6$ ) of students were concerned about the impact on their social life, including reduced opportunity to spend time with friends and difficulty making new friends. Some students ( $\mathrm{n}=6,11 \%)$ had concerns about transportation, specifically, the risk of COVID-19 infection on public transportation and the cost of commuting to campus in personal vehicles. Nineteen percent ( $\mathrm{n}=11)$ of students voiced additional concerns (e.g., mental health, international students getting deported; Table 2).

When asked about their concerns about learning online from home in Fall 2020, 64\% $(n=38)$ of students shared one concern, 24\% ( $n=14)$ shared two concerns, $10 \%(n=6)$ shared three concerns, and 2\% ( $\mathrm{n}=1)$ shared four concerns. The most common concern, shared by $58 \%$ of students ( $\mathrm{n}=34)$, was about difficulty staying focused on schoolwork during online learning (Table 3). The second most common concern regarding online learning at home was the absence of hands-on/experiential learning opportunities and in-person interactions with faculty (24\%, $\mathrm{n}=14)$. The next most common concern was the impact of staying home on their social connections (19\%, $\mathrm{n}=11)$. Students were concerned about missing their friends, feeling lonely or isolated, and having a harder time staying connected with friends. Next, students were concerned about family and home environment barriers (e.g., distractions, no privacy) to effective learning $(15 \%, n=9)$. Ten percent $(n=6)$ of students were concerned that online learning would be a "waste" of time, money, or their college experience. Finally, some students $(5 \%, \mathrm{n}=3)$ were concerned about inadequate technology or Internet connectivity. A fifth of students (19\%, n=11) voiced other concerns about learning online from home, including mental health issues, not having enough food to eat at home, visa concerns, and needing to pay for a lease on an offcampus apartment near their university (Table 3). 


\section{Discussion}

The COVID-19 pandemic will continue to disrupt universities at least through 2021, impacting two academic years for a large cohort of students. To the extent that this disruption affects students' health and education, the pandemic's impact on this generation will be far reaching. We found that students have concerns regarding both returning to campus and online learning from home during the pandemic. These concerns relate to their physical and mental health as well as their education. These findings can inform university policies going forward and future research to examine how to offset these impacts.

Universities, eager to bring students back to campus, have put safety guidelines in place and have asked students to sign pledges to adhere to those guidelines ${ }^{3}$. Critics have suggested that bringing students back to campus under any conditions is irresponsible not only because of the social nature of campus life but also because of young adults' propensity to engage in higher rates of risk taking behaviors ${ }^{17}$. Similarly, students in this study had concerns that other students would flout university safety guidelines, which could put them at risk or cause campus to shut down again. Additionally, many students expressed concern about how well their university’s safety guidelines would protect them. Students’ skepticism about the efficacy of their university's safety guidelines is an indicator that they see weaknesses that leadership may have overlooked. Universities and colleges should engage students in their safety guidelines going forward to gauge feasibility and acceptability and to determine how to engender student confidence in those guidelines.

Contrary to the media narrative that young adults don’t care if they get infected with COVID-19 ${ }^{18}$, infection was a concern reported by quarter of students in this study. Their fears have come to pass as $>130,000$ cases of COVID-19 have been reported on college campuses as 
of the beginning of October $2020{ }^{19}$. Many who were concerned about infection feared that putting others at risk, including family members. Implementing policies to address public health and safety on-campus will not be effective without considering how to ensure safety off-campus. Universities should guide commuting students on how to do so safely, and for students residing on campus, how to safely reenter their home environments when the semester ends to reduce the risk of infecting family members or causing community spread ${ }^{20}$. This will be especially important for students from historically-excluded racial/ethnic groups and low-SES students given the alarming disparities in COVID-19 morbidity and mortality in these communities ${ }^{21,22}$. The need for effective health education around COVID-19 on college campuses is highlighted by a recent study of 1,136 undergraduate students found that only $18 \%$ of students could identify the three major symptoms of COVID-19 and less than half of the students reported high health literacy ${ }^{23}$. Further research should explore how students think about their risk for COVID-19, their understanding of the risk of transmission to others, and what messages might be most effective in reducing risk taking behavior, as universities are in dire need of effective public health messaging around COVID-19.

Interestingly, impact on their ability to socialize with friends was a concern regarding both returning to campus and online learning remotely because in both scenarios, social opportunities are restricted. Although observational research shows that social media use is associated with depression in young adults ${ }^{24}$, during the pandemic, social media may be an important source of social connection. The fact that students, who are generally social media natives, crave in-person social interactions suggests that they do not view social media as a satisfactory replacement for face-to-face interaction but rather a complement. Further research is needed to explore how young adults can leverage social media in ways that enhance their mental 
and physical health (e.g., online communities devoted to health and wellbeing) ${ }^{25}$. Universities should provide on-campus opportunities for safe peer interactions and increase capacity for mental health services given the negative impacts of social isolation ${ }^{26}$. Universities can increase capacity for mental health services by expanding their offered services, increasing the number of providers, reducing barriers to access, and through intentional outreach-especially to students from underprivileged backgrounds (e.g., LGBTQ+ , students of color) ${ }^{27}$.

Students voiced many concerns related to online learning, many of which were related to educational quality, their ability to focus and learn with the approaches used by instructors during Spring 2020, and the lack of hands-on/experiential learning experiences (e.g., lab courses). Universities quickly pivoted to online learning in Spring 2020 but few had planned for this circumstance which appears to have resulted in inconsistent teaching modalities, variable quality of implementation, elimination of experiential learning, and poor utilization of innovative online teaching technologies ${ }^{28}$. A common concern among students in this study was that subsequent semesters would reflect the same lack of preparedness they experienced in the spring. Indeed, $10 \%$ of the students in our study specifically stated that online learning would be a waste of their time and money. To the extent that universities do not ensure that faculty are prepared for online instruction, the perception that online learning is substandard will persist, which will hamper efforts to increase the reach of online learning to communities that have poor access to higher education. Many innovative technologies are available to create engaging online learning experiences ${ }^{29}$ and they are used regularly in institutions that have made investments in distance learning ${ }^{30,31}$. However, many faculty in traditional universities lack familiarity with these tools and the skills to leverage them in their pedagogy ${ }^{28}$. Further, active learning strategies that are effective in STEM courses can be incorporated in online learning environments (e.g., discussion 
boards for course content) ${ }^{32,33}$. Public health experts forecast that pandemics will be increasingly common in the coming years as will natural disasters such as hurricanes and wildfires ${ }^{34,35}$ that also have the potential to make being on or traveling to a university campus unsafe. At this point, universities need to work toward developing a seamless plan for pivoting to online learning to prevent poor educational outcomes, dissatisfaction, and attrition in the face of these public emergencies ${ }^{36,37}$.

Additional concerns about online learning from home included barriers to learning in the home environment such as family obligations or lack of a private place to study and inadequate Wi-Fi or computing resources. Inadequate internet access is a barrier for many low-SES students attempting online learning ${ }^{38}$. Currently, many opportunities to use public Wi-Fi networks are restricted (e.g., public libraries, coffee shops) and without adequate access at home, low-SES students may be compelled to take gap years or drop out ${ }^{39,40}$. Additional home environment concerns include safety issues (e.g., physical/emotional/sexual abuse, drug and/or alcohol use) and food and housing insecurity ${ }^{41,42}$. Universities should consider these factors when prioritizing applications for on-campus housing. Faculty can also create flexible opportunities for course engagement when students are participating from less private spaces, such as leveraging online chats versus relying on oral contributions to class discussions. Future research is needed to better understand how the home environment impacts online learning outcomes.

This study has strengths and limitations. Due to purposive sampling, the sample is diverse with respect to race/ethnicity, gender, and SES. However, this qualitative study was not powered to compare findings by these demographic factors. Additionally, our sample does not include students who identify as races or ethnicities other than the four racial/ethnic groups selected as focus group strata, including those who identify as multiracial or indigenous/Native. 
Similarly, our sample does not include students whose gender identify is other than man or woman, nor did we ask about sexual orientation. Future research is needed to investigate how other aspects of students' identity (e.g., sexual orientation, gender identity) impact their experiences during the pandemic ${ }^{43}$.

The impact of the pandemic on higher education can be considered through the lens of the social determinants of health. Educational attainment is associated with income and employment which are strong predictors of life expectancy ${ }^{44}$. The US divestment in education and public health has set the stage for the COVID-19 pandemic to have devastating impacts on both ${ }^{45}$. Public health research is needed to examine the impact on the current generation of college students and develop programs to prevent attrition and facilitate reentry while providing adequate support to address physical and mental health impacts.

\section{Acknowledgements}

This project was supported by grants from the National Science Foundation (PI: Brown, NSF \#2028344; PI: Pagoto, co-PI: Waring, NSF \#2028341). Additional support for Dr. Pagoto was provided by National Institute of Health (NIH) grant K24HL124366.

\section{Disclosures}

No potential competing interest was reported by the authors. 


\section{References}

1. Aucejo EM, French J, Ugalde Araya MP, Zafar B. The impact of COVID-19 on student experiences and expectations: Evidence from a survey. Journal of public economics. 2020;191:104271.

2. Son C, Hegde S, Smith A, Wang X, Sasangohar F. Effects of COVID-19 on College Students' Mental Health in the United States: Interview Survey Study. Journal of medical Internet research. 2020;22(9):e21279.

3. Anderson G. Stay Apart or Stay Home. July 15 2020; https://www.insidehighered.com/news/2020/07/15/student-conduct-codes-and-pledgespromise-good-covid-19-habits. Accessed October 7, 2020.

4. $\quad$ Elias J, Troop D, Wescott D. Here’s Our List of Colleges’ Reopening Models. https://www.chronicle.com/article/heres-a-list-of-colleges-plans-for-reopening-in-thefall/?bc_nonce=vuqd0bt9s9rspr9xbuicz\&cid=reg_wall_signup. Accessed October 7, 2020.

5. Hobbs TD. Schools are Reopening, Then Quickly Closing Due to Coronavirus Outbreaks. August 17 2020; https://www.wsj.com/articles/schools-are-reopening-thenquickly-closing-due-to-coronavirus-outbreaks-11597700886. Accessed October 7, 2020.

6. Peter J. Grads face uncertain job market as coronavirus pushes companies to rescind offers. April 10 2020; https://www.usatoday.com/story/money/2020/04/10/college-gradsuncertain-job-market-offers-rescinded/2951273001/. Accessed October 10, 2020.

7. Blake S. This STEM graduate has been applying for five jobs per day - and no luck yet. July 10 2020; https://www.cnbc.com/2020/07/10/this-stem-graduate-has-been-applyingfor-five-jobs-per-dayno-luck-yet.html. Accessed October 10, 2020. 
8. Landivar LC. Disparities in STEM employment by sex, race, and Hispanic origin: American Community Survey Reports. 2013; https://www2.census.gov/library/publications/2013/acs/acs-24.pdf. Accessed 10 October 2020.

9. Olson S, Riordan D. Engage to Excel: Producing One Million Additional College Graduates with Degrees in Science, Technology, Engineering, and Mathematics. Report to the President. ERIC2012. ED541511.

10. Huckins JF, daSilva AW, Wang W, et al. Mental Health and Behavior of College Students During the Early Phases of the COVID-19 Pandemic: Longitudinal Smartphone and Ecological Momentary Assessment Study. Journal of medical Internet research. 2020;22(6):e20185.

11. Miller SG, Weaver J. Fauci says U.S. won’t get back to normal until late 2021. September 11 2020; https://www.nbcnews.com/health/health-news/fauci-says-us-won-tget-back-normal-until-late-n1239882. Accessed October 7, 2020.

12. Fisher KA, Bloomstone SJ, Walder J, Crawford S, Fouayzi H, Mazor KM. Attitudes Toward a Potential SARS-CoV-2 Vaccine: A Survey of U.S. Adults. Ann Intern Med. 2020.

13. Curseu D, Popa M, Sirbu D, Stoian I. Potential Impact of Climate Change on Pandemic Influenza Risk. In: Dincer I, Hepbasli A, Midilli A, Karakoc TH, eds. Global Warming: Engineering Solutions. Boston, MA: Springer US; 2010:643-657.

14. Tollefson J. Why deforestation and extinctions make pandemics more likely. August 7 2020; https://www.nature.com/articles/d41586-020-02341-1. Accessed October 7, 2020. 
15. Harris PA, Taylor R, Thielke R, Payne J, Gonzalez N, Conde JG. Research electronic data capture (REDCap)--a metadata-driven methodology and workflow process for providing translational research informatics support. Journal of biomedical informatics. 2009;42(2):377-381.

16. Hsieh HF, Shannon SE. Three approaches to qualitative content analysis. Qualitative health research. 2005;15(9):1277-1288.

17. Steinberg L. Expecting Students to Play It Safe if Colleges Reopen Is a Fantasy. June 15 2020; https://www.nytimes.com/2020/06/15/opinion/coronavirus-college-safe.html. Accessed October 7, 2020.

18. Parties, No Masks: Colleges Suspend Students for Flouting COVID-19 Rules. September 21 2020; https://thecollegepost.com/students-violating-covid-measures/. Accessed October 10, 2020.

19. Tracking COVID in U.S. Colleges and Universities. September 25 2020; https://www.nytimes.com/interactive/2020/us/covid-college-cases-tracker.html. Accessed October 7, 2020.

20. Jacoby B. What About the Other 85 Percent? July 23 2020; https://www.insidehighered.com/views/2020/07/23/colleges-should-be-planning-moreintentionally-students-who-commute-campuses-fall. Accessed October 10, 2020.

21. Wiemers EE, Abrahams S, AlFakhri M, Hotz VJ, Schoeni RF, Seltzer JA. Disparities in Vulnerability to Severe Complications from COVID-19 in the United States. medRxiv. 2020. 
22. Health Equity Considerations \& Racial \& Ethnic Minority Groups. July 24 2020; https://www.cdc.gov/coronavirus/2019-ncov/community/health-equity/raceethnicity.html. Accessed October 7, 2020.

23. Chesser A, Drassen Ham A, Keene Woods N. Assessment of COVID-19 Knowledge Among University Students: Implications for Future Risk Communication Strategies. Health Education \& Behavior. 2020;47(4):540-543.

24. Lin LY, Sidani JE, Shensa A, et al. Association between social media use and depression among U.S. young adults. Depression and anxiety. 2016;33(4):323-331.

25. Pagoto S, Waring ME, Xu R. A Call for a Public Health Agenda for Social Media Research. Journal of medical Internet research. 2019;21(12):e16661.

26. Armour MS. Will Shame Make Students Stop Socializing? August 21 2020; https://www.insidehighered.com/news/2020/08/21/colleges-point-fingers-studentspartying-spreading-covid-19. Accessed October 7, 2020.

27. Liu CH, Pinder-Amaker S, Hahm HC, Chen JA. Priorities for addressing the impact of the COVID-19 pandemic on college student mental health. Journal of American college health : J of ACH. 2020:1-3.

28. McMurtrie B. The Coronavirus Has Pushed Courses Online. Professors Are Trying Hard to Keep Up. . March 20 2020; https://www.chronicle.com/article/the-coronavirus-haspushed-courses-online-professors-are-trying-hard-to-keep-up/. Accessed October 10, 2020.

29. Rapanta C, Botturi L, Goodyear P, Guàrdia L, Koole M. Online University Teaching During and After the Covid-19 Crisis: Refocusing Teacher Presence and Learning Activity. Postdigital Science and Education. 2020. 
30. Chen B, Bastedo K, Howard W. Exploring Best Practices for Online STEM Courses: Active Learning, Interaction \& Assessment Design. 2018. 2018;22(2).

31. Chirikov I, Semenova T, Maloshonok N, Bettinger E, Kizilcec RF. Online education platforms scale college STEM instruction with equivalent learning outcomes at lower cost. Sci Adv. 2020;6(15):eaay5324.

32. Graham MJ, Frederick J, Byars-Winston A, Hunter AB, Handelsman J. Science education. Increasing persistence of college students in STEM. Science (New York, NY). 2013;341(6153):1455-1456.

33. Freeman S, Eddy SL, McDonough M, et al. Active learning increases student performance in science, engineering, and mathematics. Proceedings of the National Academy of Sciences of the United States of America. 2014;111(23):8410-8415.

34. Xu R, Yu P, Abramson MJ, et al. Wildfires, Global Climate Change, and Human Health. New England Journal of Medicine. 2020.

35. Sheehan MC, Fox MA. Early Warnings: The Lessons of COVID-19 for Public Health Climate Preparedness. International Journal of Health Services. 2020;50(3):264-270.

36. Mitroff II, Diamond MA, Alpaslan MC. How Prepared are America's Colleges and Universities for Major Crises? Change: The Magazine of Higher Learning. 2006;38(1):61-67.

37. Kapucu N, Khosa S. Disaster Resiliency and Culture of Preparedness for University and College Campuses. Administration \& Society. 2013;45(1):3-37.

38. Vogels EA, Perrin A, Raine L, Anderson M. 53\% of Americans Say the Internet Has Been Essential During the COVID-19 Outbreak. 2020; 
https://www.pewresearch.org/internet/2020/04/30/53-of-americans-say-the-internet-hasbeen-essential-during-the-covid-19-outbreak/. Accessed 10 October 2020.

39. Redden E. Community College Enrollments Drop This Fall. September 24 2020; https://www.insidehighered.com/news/2020/09/24/undergraduate-enrollment-falls-25percent-community-college-enrollment-75-percent. Accessed October 10, 2020.

40. Long H, Douglas-Gabriel D. The latest crisis: Low-income students are dropping out of college this fall in alarming numbers. September 16 2020; https://www.washingtonpost.com/business/2020/09/16/college-enrollment-down/ Accessed October 10, 2020.

41. Wang X, Hegde S, Son C, Keller B, Smith A, Sasangohar F. Investigating Mental Health of US College Students During the COVID-19 Pandemic: Cross-Sectional Survey Study. Journal of medical Internet research. 2020;22(9):e22817.

42. Soria KM, Horgos B, Chirikov I, Jones-White D. First-Generation Students' Experiences During the COVID-19 Pandemic. 2020; https://conservancy.umn.edu/handle/11299/214934. Accessed October 7, 2020.

43. Salerno JP, Williams ND, Gattamorta KA. LGBTQ populations: Psychologically vulnerable communities in the COVID-19 pandemic. Psychological Trauma: Theory, Research, Practice, and Policy. 2020;12(S1):S239-S242.

44. McGill N. Education attainment linked to health throughout lifespan: Exploring social determinants of health. The Nation's Health. 2016;46(6):1-19.

45. Rollston R, Galea S. COVID-19 and the Social Determinants of Health. American journal of health promotion : AJHP. 2020;34(6):687-689. 
Tables and Figures

Table 1. Characteristics of undergraduate students majoring in STEM fields, $n$ (\%)

\begin{tabular}{|c|c|}
\hline $\begin{array}{l}\text { Age (years) } \\
18 \text { years } \\
19 \text { years } \\
20 \text { years } \\
21 \text { years } \\
22 \text { years } \\
36 \text { years }\end{array}$ & $\begin{array}{c}15(24) \\
25(40) \\
15(24) \\
4(6) \\
2(3) \\
1(2)\end{array}$ \\
\hline $\begin{array}{l}\text { Gender } \\
\text { Female } \\
\text { Male }\end{array}$ & $\begin{array}{l}33(52) \\
31(48) \\
\end{array}$ \\
\hline $\begin{array}{l}\text { Race/ethnicity } \\
\text { Non-Hispanic white } \\
\text { Non-Hispanic Middle Eastern } \\
\text { Non-Hispanic Black } \\
\text { Hispanic (any race) } \\
\text { Non-Hispanic South East/East Asian } \\
\text { Non-Hispanic South Asian } \\
\end{array}$ & $\begin{aligned} 17 & (27) \\
2 & (3) \\
15 & (23) \\
13 & (20) \\
6 & (9) \\
11 & (17)\end{aligned}$ \\
\hline $\begin{array}{l}\text { Socioeconomic status (SES) } \\
\text { Low SES } \\
\text { Higher SES }\end{array}$ & $\begin{array}{l}30(47) \\
34(53) \\
\end{array}$ \\
\hline $\begin{array}{l}\text { Highest parental education } \\
\text { High school/GED } \\
\text { Trade/tech/some college/Associate's degree } \\
\text { Bachelors or higher }\end{array}$ & $\begin{array}{c}8(13) \\
5(8) \\
51(80)\end{array}$ \\
\hline $\begin{array}{l}\text { Hard for family to pay for basics } \\
\text { Not at all hard } \\
\text { Somewhat hard } \\
\text { Very hard }\end{array}$ & $\begin{array}{c}44(69) \\
20(31) \\
--\end{array}$ \\
\hline $\begin{array}{l}\text { Eligibility for federal aid programs } \\
\text { Work study } \\
\text { Pell grant } \\
\text { Other need-based loans or grants (e.g., Stafford Loans) }\end{array}$ & $\begin{array}{l}15(23) \\
18(28) \\
12(19)\end{array}$ \\
\hline $\begin{array}{l}\text { Class rank in college in Spring } 2020 \\
1^{\text {st }} \text { year/freshman } \\
2^{\text {nd }} \text { year/sophomore } \\
3^{\text {rd }} \text { year/junior } \\
4^{\text {th }} \text { year/senior* }\end{array}$ & $\begin{array}{l}40(63) \\
16(25) \\
7(11) \\
1(2)\end{array}$ \\
\hline
\end{tabular}

* This participant reported planning on being enrolled full-time in fall 2020. 
Table 2. Concerns about going back to campus in fall 2020 among undergraduate students majoring in STEM fields $(\mathrm{N}=57)$

\begin{tabular}{|c|c|c|}
\hline Theme & $\mathbf{N}(\%)$ & Illustrative examples* \\
\hline $\begin{array}{l}\text { Student noncompliance to } \\
\text { campus COVID-19 } \\
\text { prevention guidelines }\end{array}$ & $16(28)$ & $\begin{array}{l}\text { "My college has a lot of students, making social } \\
\text { distancing very difficult. I also don't trust my peers } \\
\text { to all be cautious and take the adequate preventative } \\
\text { measures to slow covid. Some issues are very } \\
\text { political, like mask wearing, and I can see how some } \\
\text { people might not change their views. This will } \\
\text { impact our efforts as a collective.” } \\
\text { "I'm not sure I trust other students to take the } \\
\text { necessary precautions to stop the spread of the } \\
\text { virus.” } \\
\text { "There being a huge spread of the virus due to young } \\
\text { people not wanting to wear masks.” }\end{array}$ \\
\hline $\begin{array}{l}\text { Becoming infected with } \\
\text { COVID-19, including } \\
\text { subsequently infecting } \\
\text { family members }\end{array}$ & $15(26)$ & $\begin{array}{l}\text { "I really don't want to contract the virus and have } \\
\text { that impact my studies.” } \\
\text { “...that I might catch COVID from them, and as an } \\
\text { immunocompromised individual, that could be } \\
\text { deadly for me.” } \\
\text { "I am concerned that there will be an outbreak and as } \\
\text { a result, we will have to go home and potentially } \\
\text { affect our families who may not survive COVID- } \\
\text { 19.” } \\
\text { “As someone who has various family members who } \\
\text { are vulnerable like infants and elderly, I wouldn't } \\
\text { want their health to be in jeopardy because of me.” }\end{array}$ \\
\hline $\begin{array}{l}\text { Poor quality of online or } \\
\text { hybrid courses, lack of } \\
\text { hands-on/experiential } \\
\text { learning opportunity, and } \\
\text { inadequate access to } \\
\text { campus resources and } \\
\text { facilities }\end{array}$ & $15(26)$ & $\begin{array}{l}\text { "My school said 'most' Fall courses will be online, } \\
\text { but hasn't clarified which ones. All of the courses I } \\
\text { still need to qualify for transfer to a [UNIVERSITY } \\
\text { OF STATE], are supposed to have physical lab } \\
\text { experiments because we NEED that experience. Now } \\
\text { we will not get the same experience.” } \\
\text { "Inadequate access to facilities whether it be tutoring } \\
\text { centers or the gym” }\end{array}$ \\
\hline $\begin{array}{l}\text { Inadequate university plans } \\
\text { to prevent an outbreak and } \\
\text { financial repercussions of } \\
\text { sudden campus closing }\end{array}$ & $14(25)$ & $\begin{array}{l}\text { "That we are going to get sent back home after they } \\
\text { receive tuition payments.” } \\
\text { "I feel like campuses are jumping the gun by opening } \\
\text { back up. I predict that [UNIVERSITY’S] 'hybrid' }\end{array}$ \\
\hline
\end{tabular}




\begin{tabular}{|c|c|c|}
\hline & & $\begin{array}{l}\text { learning plan will go completely online due to a } \\
\text { spike in COVID cases.” }\end{array}$ \\
\hline $\begin{array}{l}\text { Reduced opportunity to } \\
\text { socialize }\end{array}$ & $6(11)$ & $\begin{array}{l}\text { "Everything shutting back down, campus/social life } \\
\text { inhibited, organizations formatted differently." } \\
\text { "Will not be able to see friends and make new } \\
\text { friends.” }\end{array}$ \\
\hline $\begin{array}{l}\text { Challenges commuting to } \\
\text { campus, including risk of } \\
\text { infection on public } \\
\text { transportation and cost and } \\
\text { logistics driving }\end{array}$ & $6(11)$ & $\begin{array}{l}\text { "There is limited housing, so I'll probably have to } \\
\text { stay home and commute, but my car right now is } \\
\text { broken down. Also, we don't know how parking } \\
\text { passes will be sold or if there will even be enough." } \\
\text { "I rely on public transportation to get to school, but } \\
\text { we have been informed that less buses will be } \\
\text { running and with a smaller capacity. I am concerned } \\
\text { of not being able to make it on time, or getting there } \\
\text { too early and having nowhere to wait since they are } \\
\text { not allowing students in the hallways of my } \\
\text { academic building." }\end{array}$ \\
\hline Other concerns & $11(19)$ & $\begin{array}{l}\text { "In-person classes getting canceled would mean my } \\
\text { international friends get deported." } \\
\text { "As an RA I can't opt out of going back otherwise I'll } \\
\text { have to resign my position.” }\end{array}$ \\
\hline
\end{tabular}

* Portion of response coded as each theme are presented as illustrative examples. Identifying information (e.g., name of university) have been removed and replaced with generic descriptor in square brackets (e.g., [UNIVERSITY]) to protect participant confidentiality. 
Table 3. Concerns about staying home and learning online in fall 2020 among undergraduate students majoring in STEM fields $(\mathrm{N}=59)$

\begin{tabular}{|c|c|c|}
\hline Theme & $\mathbf{N}(\%)$ & Illustrative examples* \\
\hline $\begin{array}{l}\text { Difficulty staying } \\
\text { focused on } \\
\text { schoolwork or } \\
\text { staying motivated in } \\
\text { online courses }\end{array}$ & $34(58)$ & $\begin{array}{l}\text { "I do not have the self discipline to stay on top of } \\
\text { schoolwork while I'm ONLY ever at home. I relied so much } \\
\text { on the drop in tutoring m before and it's not the same now." } \\
\text { "I am concerned about being able to use my time well } \\
\text { because I do not do well in unstructured situations." } \\
\text { "I concentration and productivity decreased significantly } \\
\text { when classes moved online, and I did not felt like I was } \\
\text { learning as much as I did when they were in person." }\end{array}$ \\
\hline $\begin{array}{l}\text { Lack of hands- } \\
\text { on/experiential } \\
\text { learning or in-person } \\
\text { interactions will } \\
\text { hinder learning } \\
\end{array}$ & $14(24)$ & $\begin{array}{l}\text { "I think that the lack of hands-on experience will be a } \\
\text { deterrent to the learning process." } \\
\text { "Lack of real life instruction and help." }\end{array}$ \\
\hline $\begin{array}{l}\text { Negative impact on } \\
\text { social life, including } \\
\text { missing friends or } \\
\text { feeling lonely and } \\
\text { challenges staying } \\
\text { connected with } \\
\text { friends from afar }\end{array}$ & 11 (19) & $\begin{array}{l}\text { "I am concerned that I will be missing out on meeting new } \\
\text { people and networking within the major I would like to } \\
\text { switch to, and therefore missing out on opportunities. I am } \\
\text { worried that I will no longer have friends to go back due to } \\
\text { the fact that I am not returning but others in my group are." } \\
\text { "Will be lonely and unhealthy at home." } \\
\text { "Lack of social interaction." }\end{array}$ \\
\hline $\begin{array}{l}\text { Family and home } \\
\text { environment as } \\
\text { barriers to learning }\end{array}$ & $9(15)$ & $\begin{array}{l}\text { "In regards to staying at home with my parents, it is an } \\
\text { option, and my biggest concern is that I will not be able to } \\
\text { focus } 100 \% \text { on schoolwork, as my parents need help with } \\
\text { stuff around the house, and my siblings are needy in regards } \\
\text { to attention. So I believe that my schoolwork will suffer } \\
\text { greatly if I stay at home." } \\
\text { "The environment of my house living with } 7 \text { other people } \\
\text { makes it hard to focus." } \\
\text { "My ability to work efficiently while in my home full of } \\
\text { distractions like video games." }\end{array}$ \\
\hline $\begin{array}{l}\text { Distance learning } \\
\text { will be a waste of } \\
\text { time, money, or their } \\
\text { college experience }\end{array}$ & $6(10)$ & $\begin{array}{l}\text { "I think the price that I am paying to be here is not reflected } \\
\text { in the education I am receiving online. I do not want to be } \\
\text { ripped off because I am paying so much for so little." } \\
\text { "Waste of time and money losing fun senior year with } \\
\text { friends." }\end{array}$ \\
\hline
\end{tabular}




\begin{tabular}{|l|c|l|}
\hline $\begin{array}{l}\text { Inadequate } \\
\text { technology or } \\
\text { Internet connectivity }\end{array}$ & $3(5)$ & $\begin{array}{l}\text { "My wifi is super slow and laggy. I'm worried if it will be } \\
\text { fast enough for online exam proctoring (ProctorU)." } \\
\text { "I will probably run into frequent connectivity issues." }\end{array}$ \\
\hline Other concerns & $11(19)$ & $\begin{array}{l}\text { "Depression." } \\
\text { "visa status concerns." }\end{array}$ \\
\hline
\end{tabular}

* Portion of response coded as each theme are presented as illustrative examples. Identifying information (e.g., name of university) have been removed and replaced with generic descriptor in square brackets (e.g., [UNIVERSITY]) to protect participant confidentiality. 